Mansour, N. (2010). The impact of the knowledge and beliefs of Egyptian science teachers in integrating an STS based curriculum. Journal of Science Teacher Education 21(5),513-534. DOI 10.1007/s10972-010-9193-0.

\title{
Impact of the knowledge and beliefs of Egyptian science teachers in integrating a STS based curriculum: A sociocultural perspective
}

\author{
NASSER MANSOUR \\ Graduate School of Education, University of Exeter, St. Luke's Campus, Exeter EX1 \\ 2LU, UK
}

\section{Abstract}

The failure of much curriculum innovation has been attributed to the neglect by innovators of teachers' perceptions. The purpose of this study was to investigate inservice science teachers views of integrating Science, Technology and Society (STS) issues into the science curriculum and identify the factors that influence their decisions concerning integrating STS issues (or not). The study used mixed methods (questionnaire and interviews) with Egyptian science teachers who teach science courses for 12- to 14-year-old students. The findings indicate that unless curriculum developers take account of teachers' beliefs and knowledge and the sociocultural factors that shape or influence those beliefs in designing and planning new STS curriculum materials, these materials are unlikely to be implemented according to their intended plan.

Keywords Science Technology and society ; STS curriculum; Sociocultural theory; Egyptian science teachers ; Pedagogical beliefs 


\section{Theoretical framework}

\section{Teachers' knowledge, beliefs and decision-making}

The study of teachers' beliefs forms part of the process of understanding how teachers conceptualize their work. Beliefs influence people's knowledge acquisition and interpretation, their task selection and organization, and their ways of understanding. While beliefs have been described as the most valuable psychological construct for teacher education, they are also one of the most difficult to define, since a belief "does not lend itself to empirical investigations" (Pajares, 1992, p. 308). In reviewing the research on this topic, Pajares refers to beliefs as a "messy construct" (p. 309). Loucks-Horsley et al.(1998) argued that "beliefs are more than opinions: they may be less than ideal truth, but we are committed to them" (P. 27). Pajares (1992) notes that "the difficulty in studying teachers' beliefs has been caused by definitional problems, poor conceptualisation, and differing understandings of beliefs structures" (P.307). As has been noted by researchers in other fields, "belief" is not an easily defined concept (Cantu, 2001). Pajares (1992) suggests that studying educational beliefs is in danger of becoming what Nespor (1987) calls an 'entangled domain'. For the purpose of the present paper, the concept of belief is used to characterize a teacher's idiosyncratic unity of thought about objects, people, events and their characteristic relationships, which affect his/her planning and interactive thoughts and decisions. In an attempt to clarify the meaning of "belief", Pajares expresses the need to distinguish between belief and knowledge and explains that knowledge is based on objective fact, while beliefs are based on evaluation and judgment. while Kagan (1992) argues that most of a teacher's professional knowledge can be regarded as belief, claiming that knowledge is considered a belief that has been affirmed as true on the basis of objective proof or consensus of opinion. 
A further distinction between beliefs and knowledge is that while knowledge often changes, beliefs are "static". In addition, whereas knowledge can be evaluated or judged, such is not the case with beliefs since there is usually a lack of consensus about how they are to be evaluated. Furthermore, there do not appear to be any clear rules for determining the relevance of beliefs to real world events. While there are doubtless other distinctions that could be made between the two constructs, a better understanding may be gained by exploring the relationship between the two, and by considering beliefs as a form of knowledge. This form of knowledge can be referred to as personal knowledge (Nespor, 1987). Kagan (1992) refers to beliefs as a "particularly provocative form of personal knowledge" and argues that most of a teacher's professional knowledge can be regarded more accurately as belief.

The powerful influence of teachers' beliefs on the gaining of knowledge related to STS (Science, Technology and Society) issues was highlighted by author's findings (2008a). In this sense, the settled or developed 'schema' of teachers' beliefs acted as an information organizer and priority categorizer, and in turn controlled the way it could be used (Author, 2008b). In the interactions between knowledge and beliefs, beliefs controlled the gaining of knowledge and knowledge influenced beliefs. This suggested that teachers needed to create their own STS knowledge through a process of interaction between their existing beliefs and knowledge base, and the new ideas with which they came into contact (Richardson, 1997). Rubba and Harkness (1993) suggested that STS courses focusing particularly on the nature of science and technology and their interactions within society might appear to be an appropriate way to help science teachers develop an understanding of STS and integrate an STS based curriculum.

Teachers construct their own meaning of any curriculum as they negotiate an orientation towards it and decide what, if anything, to implement in their classroom (Aikenhead, 2005). 
In this sense, teacher participation in the curriculum planning process is considered essential, whether in the defining of problems or the presenting of concrete solutions in the form of programmes of study (Ben-Peretz, 1980). The failure of much curriculum innovation has been attributed to the neglect by innovators of teachers' perceptions (Sutherland, 1981), and it seems that teachers' own interests and concerns are only rarely allowed to influence or direct the choices made by curriculum developers (Ben-Peretz, 1980).

\section{Science Teachers and STS Curriculum}

Over the years, researchers have studied teachers' rejection, acceptance, and idiosyncratic modulation of an intended STS science curriculum. Several general conclusions about teachers' orientations can be drawn from this literature. First, a small proportion of science teachers are always supportive of an STS science curriculum. Thus, there will always be a few science teachers who teach from an STS point of view. These teachers resist and some actively undermine any STS innovation in school science (Aikenhead, 2005).

STS teaching requires new models for pre- and in-service teacher education. Yager (1996) argues that the greatest problem associated with shifts to STS teaching is the failure of most teachers to have personally experienced study and learning as STS, that is, learning in the context of human experiences. Science teachers may not have an adequate understanding of the nature of science and technology and their interactions. This could be a factor in the degree to which science teachers integrate STS curriculum into science instruction, the methods used to integrate STS into science instruction, and the quality of the STS instruction (Author, 2008a). This can provide us with insights as to why teachers may not be implementing or are struggling to implement STS issues in the classrooms (Author, 2008b). According to Za'rour (1987), teachers' unfamiliarity with the required teaching models and approaches could hinder the introduction of an STS curriculum in schools. Similarly, Rubba 
(1991) suggests that STS has not attained the level of implementation recommended by the NSTA because the majority of the science teachers are not prepared to teach STS.

As substantiated by years of research, a teacher's values, assumptions, beliefs, ideologies, professional self-identity, status, and loyalties must be more or less in harmony with an STS approach to science education before a teacher will teach an STS curriculum. Changing any one of these influences on a teacher's orientation is very difficult for most middle-of-the-road teachers, and is usually impossible for traditional enthusiasts (Aikenhead, 2005). Fensham (1988) refers to science teachers stating that the disciplinary background of science had not prepared them for STS. An undergraduate education in a science discipline rarely allows students to be aware of controversy in pure science itself, nor do its patterns of teaching and learning usually include discussion of the merits of arguments, or debate about the quality of empirical evidence or the concepts on which this is based.

Carroll (1999) argues that teachers must be involved in the actual development of the STS curriculum so that they can build their knowledge concerning STS themes of teaching and learning and reform their beliefs along the way. They must have the opportunity to develop their views and beliefs about STS. In the same vein, Thirumarayana (1998) suggests that before STS instruction can be implemented, teachers must first build upon their interests and use them to develop conceptual understanding. The need for information concerning the beliefs that teachers hold about curriculum implementation and the origins of these beliefs is central to the realization of any curriculum implementation goal. As Munby points out, "teachers' beliefs and principles are contextually significant to the implementation of innovations" (1984, p. 28). Research also supports the idea that teachers are crucial agents of change in educational reform, and that teachers' beliefs are precursors to change (Fishbein \& Ajzen, 1975; Pajares, 1992). 


\section{The context of the study}

The school system in Egypt consists of 3 stages. The first stage is the primary stage which consists of 6 years. Children start at 6 years, and leave at 12 years. The second stage is the preparatory stage, which consists of 3 years; students start at 12 years, and leave at 14 years. The third stage is the secondary stage which consists of 3 years, with students starting at 15 years, and leaving at 17 years. The Ministry of Education is the only authority that determines the educational curricula, syllabuses, methods of teaching, educational targets, and the roles of the teachers and learners. Curriculum guidelines for science are determined through a system of committees at the state level. The science subject committee is composed of consultants, supervisors, experts, professors of science education and experienced science teachers. Once the committee reaches agreement, the curriculum guidelines are then referred to the Supreme Council of Pre-University Education for official release. Each governorate is responsible for implementation of the guidelines.

Science has been a basic subject in the central National Curriculum (NC) since the 1960s, having traditionally included integrated science at primary and preparatory levels, and separated science (chemistry, physics and biology) at the secondary level. In 2003, the Ministry of Education (MoE) in Egypt issued the National Standards for Education in Egypt (NSEE) as a national project, aiming to set comprehensive quality educational standards in Egypt and raising awareness about quality learning. The standards seek to increase the authority of the central administration in setting educational goals and standards for accountability, and to provide the necessary support for reforms (UNESCO, 2006). The NSEE emphasised three dimensions of the relationship between science, technology and society: Science and technology, Science from a societal and personal perspective and the history and nature of science. 
It is clear from these fields and their distribution in the different grades that there is an emphasis on including fields concerned with the interactive relationship between science, technology and society in all grades of science education in Egypt. However, the main question is if Egyptian science teachers' beliefs, knowledge and values about STS issues will enable this curriculum reform to take place in practice.

\section{Methodological framework}

'The goal of a sociocultural approach is to explicate the relationships between human action, on the one hand, and the cultural, institutional, and historical situations in which this action occurs, on the other' (Wertsch et al. 1995: 11). The basic premise of sociocultural theories is that learning is social, and mediated by cultural objects. Sociocultural theorists view humans as not having direct access to the empirical world but, rather, access to the world "Only indirectly, or mediately ... this applies both with regard to how humans obtain information about the world and how they act on it - two processes that are usually viewed as being fundamentally intertwined ... meditational means or cultural tools ... must play an essential role in the basic formulation of sociocultural research. In particular they provide the link or bridge between the concrete actions carried out by individuals and groups, on the one hand, and cultural, institutional, and historical settings, on the other.” (Wertsch et al. 1995: 21)

The human organism develops within a sociocultural milieu and is influenced by cultural and social forces in which the individual is embedded (Wertsch, 1991). Wertsch argues that it is through the analysis of the specific sociocultural contexts of utterances that we can gain insight into how cultural, historical, and institutional factors shape instrumental functioning. In his words, "It is the sociocultural situatedness of mediated action that provides the essential link between the cultural, historical and institutional setting, on the one hand and the mental 
functioning of the individual on the other'” (p. 48). According to Vygotsky (1978), humans are born into a preexisting world of culturally established tools and artifacts, which are the material embodiment of important cultural ideas and adaptations, passed down through history, that extend the reach of human activity and understanding.

Sociocultural theory proposes that knowledge is bound to specific contexts of social practice and is always embedded in a social context shared within a group or community. Each context within which social interaction takes place is different. Schools, homes and classrooms all have their own language and customs, and these influence the social interactions that take place within them. Teachers are "agents of change" regarding educational reform, and their beliefs must not be ignored. Their beliefs are at the "core of educational change" (MamlokNoaaman, et al, 2007). This study uses a sociocultural lens for understanding the active interplay among science teachers and their cultural, historical and institutional setting when gaining knowledge or using this knowledge, and how these settings influenced their decision reforming the science curriculum toward a STS-based curriculum. In this sense, the study poses these questions;

- What are science teachers' beliefs about the priority of integrating Science, Technology and Society (STS) issues in the science curriculum?

- What is science teachers' perceived knowledge regarding STS related issues?

- What are the factors that influence teachers' decisions concerning integrating STS issues into the science curriculum?

\section{Methodology}

The basic approach was to compare two groups of science teachers: those who prefer to include STS issues as part of the integrated curriculum in their science courses, and those who did not, and to find out how they would prefer (or not) to address these issues. This study used a mixed methods methodology combining quantitative and qualitative approaches. A 
quantitative approach using a questionnaire was used to identify teachers' perceived knowledge about STS issues, their views about integrating STS in the curriculum, and resources of knowledge about STS issues. A qualitative approach using semi-structured interviews was used to explain the results that emerged from the questionnaire, and to identify sociocultural factors that influence teachers' knowledge and decisions about STS issues and direct them to particular ways of knowing about STS issues.

\section{Data collection}

The techniques of data collection used in this study have potential strengths and weaknesses. One way to emphasize the strengths and minimize the weaknesses is to use complementary multiple methods of data collection for triangulation (Denzin \& Lincoln, 2000). Two types of triangulation were adopted: methodological triangulation and researcher-participant triangulation. The first refers to the use of multiple data collection methods (in this case, questionnaires and interview) to avoid reliance on one method in exploring participants' beliefs. The second involves respondent validity of the data collection with the participants, which occurred during the interviews as participants were asked to confirm whether their ideas were interpreted accurately. After the interviews were finished, member checks were conducted with participants in the study through email. The participating teachers reviewed the interpretations and constructions of the data by reading the narratives based on the interviews to verify.

\section{Questionnaire}

I designed a questionnaire to measure teachers' views of integrating STS issues into the science curriculum (see appendix A). The questionnaire consisted of three dimensions, which measured (i) science teachers' views about the importance of including STS issues in the science curricula; (ii) science teachers' knowledge of STS issues; and (iii) teachers' sources of knowledge of the issues. The questionnaire used in this study was modified from an earlier 
survey developed by Bybee and Mau (1986) for use with science educators (Bybee, 1984) and science teachers (Bybee \& Bonnstetter, 1986). Bybee and Mau's questionnaire serves very well the current study questions concerning science teachers. The STS issues included in Bybee and Mau's (1986) survey covered the content of preparatory science curriculum (ages 12-14) in Egypt. Also, these STS issues reflect the Ministry of Education's (MoE) future strategy of the Education in Egypt, as outlined in Mubarak and Education towards Excellent Education issued by the MoE in 2006. A pilot study was used to construct the questionnaire and to determine its validity and reliability. In this research, Cronbach's coefficient alpha was used with 126 science teachers (a sample for the pilot study) to calculate the internal consistency coefficients of the items included in the questionnaire. The result of the reliability analysis was 0.81 , showing that the items in the questionnaire had a satisfactory discriminating power and a high internal consistency.

\section{Interviews}

The interview questions were initially constructed through reviewing the previously mentioned research concerning influences affecting teachers' decisions to integrate STS issues and the introduction of new curricula or innovations within science education (see, e.g., Rubba, 1991; Tal et al, 2001; Levitt, 2001; Tsai, 2002; Gayford, 2002; Author, 2008b). Examples of the interview questions are:

- What contribution should the study of STS issues make to the science curriculum?

- Why do you think it is important that STS is integrated into the science curriculum?

- How do you deal with your own lack of detailed knowledge of STS issues?

- What skills are important for the teacher to have to teach STS issues?

The interviews were audio-taped and transcribed immediately afterwards, with the transcripts being returned to each of the teachers for their scrutiny, confirmation or criticism before the 
beginning of the next interview. After each interview an initial analysis of the interview was made and notes written on a covering sheet to act as a framework for subsequent questions. All the interviews lasted for 30 to 45 minutes, and each interviewee had 3 or 4 interviews.

Interviews were carried out in Arabic as both the researcher and the participants were native speakers. In this way, the participants were able to express their beliefs comfortably without any language barrier. The data were also analyzed in Arabic so as not to lose the actual meaning of the participants' explanations in the translation process. The parts to be quoted in the final report of the study were translated into English at the end of the data analysis process. The quality and meaningfulness of these translations were checked with the help of a native Arabic speaker who specialist on English at university and a native English speaker.

\section{Sample}

The entire questionnaire sample was randomly chosen from 30 preparatory schools in Gharbia Governorate, which is the tenth largest governorate of Egypt. A variety of teacher qualifications, specialists in science, teaching experience, age, and school locations were represented. The questionnaire was sent to 250 teachers. A total of 162 Egyptian preparatory science teachers responded to the questionnaire. After analyzing the questionnaires, maximum variation strategy was used to sample 12 teachers with diverse beliefs about integrating STS issues, including teachers who have a positive attitude to STS and others who have a negative attitude, and teachers with a variety of knowledge about STS. The sampling was designed to include a broad variety of informant experience, based on gender, unique teaching situations, a variety of teaching expertise (novices vs. experienced teachers), and varied experiences of teaching at different preparatory grade levels. These teachers are represented in this study by letters (A to L). 


\section{Data analysis}

A quantitative data analysis using the SPSS package was used to analyze the questionnaire to identify teachers' views and knowledge about STS issues, and also describe their knowledge sources of STS. Interviews with twelve teachers were then analysed qualitatively by categorising their statements, based on the views of the teachers about integrating STS issues into the science curriculum and the factors that influence teachers' decisions to integrate such issues (or not).

\section{Results}

\section{Questionnaire results}

The importance of including the STS issues in the science curriculum

Science teachers were provided with a list of twelve common issues related to STS and asked to rank them in order of importance of integrating these issues into the science curriculum. The ordering of the priorities consisted of twelve ranks graded by value. To compute the average priority index, I carried out the following procedures:

1. The first rank was given 12 marks, the second 11 marks, and so on.;

2. The rate of the priority of the rank was multiplied by its frequency;

3. The outcome of the multiplication of every field or category was summed;

4. The summed outcome was divided by the number of the subjects, then the outcome of the division represented the the "average priority index". The ordering of the priorities consisted of 12 ranks graded according to the value of the priority: the "average priority index".

Table 1: Teachers' Priority frequencies and means of STS issues

\begin{tabular}{|l|l|l|l|l|l|l|l|l|l|l|l|l|c|c|}
\hline STS Issues & 12 & 11 & 10 & 9 & 8 & 7 & 6 & 5 & 4 & 3 & 2 & $\begin{array}{c}\text { Average } \\
\text { Priority } \\
\text { Index }\end{array}$ & \begin{tabular}{c} 
Order \\
\hline
\end{tabular} \\
\hline
\end{tabular}




\begin{tabular}{|l|c|c|c|c|c|c|c|c|c|c|c|c|c|c|}
\hline $\begin{array}{l}\text { Air pollution } \\
\text { and quality }\end{array}$ & 384 & 308 & 490 & 135 & 104 & 35 & 66 & 35 & 8 & 0 & 0 & 0 & 9.66 & 1 \\
\hline $\begin{array}{l}\text { Water } \\
\text { quality and } \\
\text { recourses }\end{array}$ & 840 & 132 & 60 & 81 & 120 & 42 & 24 & 25 & 40 & 30 & 10 & 1 & 8.67 & 2 \\
\hline $\begin{array}{l}\text { Human } \\
\text { health }\end{array}$ & 180 & 385 & 300 & 171 & 120 & 91 & 42 & 15 & 20 & 24 & 20 & 2 & 8.45 & 3 \\
\hline $\begin{array}{l}\text { Population } \\
\text { growth }\end{array}$ & 96 & 132 & 150 & 225 & 152 & 210 & 108 & 50 & 48 & 18 & 8 & 3 & 7.40 & 4 \\
\hline $\begin{array}{l}\text { Hazardous } \\
\text { substances }\end{array}$ & 60 & 165 & 140 & 135 & 88 & 175 & 120 & 95 & 84 & 60 & 14 & 6 & 7.00 & 5 \\
\hline $\begin{array}{l}\text { War } \\
\text { Technology }\end{array}$ & 120 & 121 & 190 & 90 & 120 & 84 & 90 & 105 & 104 & 21 & 20 & 6 & 6.61 & 6 \\
\hline Land use & 204 & 110 & 140 & 63 & 104 & 28 & 144 & 70 & 100 & 60 & 20 & 4 & 6.46 & 7 \\
\hline $\begin{array}{l}\text { Nuclear } \\
\text { reactors }\end{array}$ & 60 & 143 & 100 & 162 & 88 & 70 & 60 & 100 & 84 & 60 & 24 & 12 & 5.94 & 8 \\
\hline $\begin{array}{l}\text { Energy } \\
\text { shortage }\end{array}$ & 24 & 110 & 60 & 153 & 24 & 105 & 84 & 150 & 48 & 96 & 20 & 11 & 5.46 & 9 \\
\hline $\begin{array}{l}\text { Mineral } \\
\text { resources }\end{array}$ & 2 & 11 & 30 & 90 & 80 & 175 & 90 & 100 & 80 & 75 & 44 & 19 & 4.91 & 10 \\
\hline $\begin{array}{l}\text { World } \\
\text { hunger and } \\
\text { food } \\
\text { production }\end{array}$ & 12 & 12 & 40 & 72 & 72 & 161 & 114 & 95 & 84 & 57 & 42 & 17 & 4.80 & 11 \\
\hline $\begin{array}{l}\text { Extinction of } \\
\text { Plants and } \\
\text { animals }\end{array}$ & 1 & 0 & 20 & 117 & 120 & 105 & 90 & 75 & 112 & 75 & 26 & 5 & 4.60 & 12 \\
\hline
\end{tabular}

As shown in Table 1, issues that related to air pollution, water quality and resources issues, and human health and disease were considered the most important, with a sequential priority mean of 7.66, 7.31, and 7.03. Issues related to overpopulation, hazardous substances, land use, and nuclear reactors took the middle position with a priority mean of $5.56,5.39,5.18$, and 4.65 sequentially. Issues of energy shortages, world hunger and food resources, and extinction of plants and animals came last, with a sequential priority mean of $4.57,3.87$, and 3.73.

\section{Science teachers' perceived knowledge of the STS issues}

How knowledgeable are science teachers about STS issues? Teachers' responses are summarised in Table 2. Only over $11 \%$ of science teachers indicated that they are very knowledgeable about Air pollution and quality (the top ranked issue), Water quality and 
recourses, Human health, Population growth, and Hazardous substances. A larger percentage of teachers (over 30\%) considered themselves as moderately knowledgeable about Air pollution and quality and Human health. A considerable percentage of the teachers $(22.8 \%$ $53.7 \%$ ) claimed they were only slightly knowledgeable about STS issues. Between a quarter and more than half of science teachers think they are not knowledgeable concerning STS issues.

Table 2: Frequencies of teachers' perceived knowledge of the STS issues

\begin{tabular}{|l|c|c|c|c|}
\hline \multicolumn{1}{|c|}{ STS Issues } & $\begin{array}{c}\text { Very } \\
\text { knowledgeable } \\
\%\end{array}$ & $\begin{array}{c}\text { Moderately } \\
\text { knowledgeable } \\
\%\end{array}$ & $\begin{array}{c}\text { Slightly } \\
\text { knowledgeable } \\
\%\end{array}$ & $\begin{array}{c}\text { not } \\
\text { knowledgeable } \\
\%\end{array}$ \\
\hline Air pollution and quality & 12.3 & 32.2 & 22.8 & 32.7 \\
\hline Water quality and recourses & 14.2 & 19.1 & 31.5 & 35.2 \\
\hline Human health & 13.3 & 30.5 & 35.8 & 20.4 \\
\hline Population growth & 11.7 & 25.3 & 30.3 & 32.7 \\
\hline Hazardous substances & 11.1 & 18.5 & 37.7 & 32.7 \\
\hline War Technology & 9.8 & 20.5 & 31.6 & 38.1 \\
\hline Land use & 6.8 & 16 & 53.7 & 23.5 \\
\hline Nuclear reactors & 3.7 & 14.2 & 42.6 & 39.5 \\
\hline Energy shortage & 2.5 & 13.6 & 35.2 & 46.3 \\
\hline Mineral resources & 2.7 & 13.2 & 40.8 & 43.3 \\
\hline $\begin{array}{l}\text { World hunger and food } \\
\text { production }\end{array}$ & 2.5 & 14.8 & 28.4 & 54.3 \\
\hline Extinction of Plants and animals & 2.5 & 11.7 & 22.8 & 63 \\
\hline
\end{tabular}

The results presented in Tables 1 and 2 indicate the consistency between teachers' perceived knowledge of STS issues and their views about the importance of integrating these issues in the science curricula. For example, teachers considered Air pollution and quality, Water quality and recourses, Human health, Population growth, and Hazardous substances to have a high priority for integration in science curricula. As shown in Table 2 these are the issues that teachers claimed to be very knowledgeable about. The STS issues that teachers have no knowledge about (e.g. energy shortages, world hunger and food resources, and extinction of plants and animals) were not so likely to be recommended for integration in the science curriculum. 
As table 3 (below) shows, the knowledge of $18.8 \%$ of teachers about STS issues came from university education. This indicates the small contribution of university education in making teachers knowledgeable about STS issues. The contribution of in-service training programmes to developing knowledge of the issues among teachers was zero, since there are no programmes to teach and spread awareness of STS issues among science teachers. The use among $20.8 \%$ of teachers of books and journals as a source of knowledge about the issues was low but reasonable, considering the high prices of books and the limited incomes of teachers in Egypt. Books and journals, as confirmed by the teachers in the interviews, should be provided to school libraries in sufficient numbers. With regard to the use of school textbooks, it was found that the percentage of their use as a learning resource about STS issues was $52.4 \%$. This finding means that textbooks were the main learning resource for STS among teachers, which could well have limited their knowledge about STS issues to being the same as that of their students.

Table 3: Teachers' sources of STS issues

\begin{tabular}{|l|c|c|c|c|c|c|c|}
\hline \multirow{2}{*}{ STS Issues } & \multicolumn{7}{|c|}{ Percentages of teachers' sources about STS issues } \\
\cline { 2 - 8 } & $\begin{array}{l}\text { Pre- } \\
\text { service }\end{array}$ & $\begin{array}{c}\text { In-service } \\
\text { Training }\end{array}$ & $\begin{array}{c}\text { Books \& } \\
\text { magazines }\end{array}$ & $\begin{array}{l}\text { School } \\
\text { textbooks }\end{array}$ & $\begin{array}{l}\text { Audio/ visual } \\
\text { media }\end{array}$ & Friends & Internet \\
\hline $\begin{array}{l}\text { Air pollution and } \\
\text { quality }\end{array}$ & 32.1 & 0 & 17.3 & 85.8 & 81.5 & 6.8 & 1.2 \\
\hline $\begin{array}{l}\text { Water quality and } \\
\text { resources }\end{array}$ & 6.2 & 0 & 11.1 & 86.4 & 85.2 & 3.7 & 4.3 \\
\hline Human health & 24.7 & 0 & 37.7 & 56.2 & 78.4 & 24.1 & 7.4 \\
\hline Population growth & 14.8 & 0 & 30.2 & 58.0 & 76.5 & 23.5 & 9.9 \\
\hline Hazardous substances & 16 & 0 & 17.9 & 28.4 & 64.2 & 6.2 & 8.6 \\
\hline War Technology & 17 & 0 & 23 & 10.2 & 70 & 1.2 & 5.9 \\
\hline Land use & 12 & 0 & 12.3 & 39.5 & 64.2 & 9.3 & 4.9 \\
\hline Nuclear reactors & 22.2 & 0 & 22.8 & 25.9 & 67.9 & 4.3 & 14.2 \\
\hline Energy shortage & 30.9 & 0 & 19.1 & 51.9 & 63.0 & 7.4 & 2.5 \\
\hline Mineral resources & 22.2 & 0 & 19.3 & 40.8 & 38.4 & 4.6 & 6.4 \\
\hline $\begin{array}{l}\text { World hunger and } \\
\text { food production }\end{array}$ & 16 & 0 & 27.2 & 46.9 & 64.8 & 12.3 & 0.6 \\
\hline Plants & 13.6 & 0 & 13.0 & 45.1 & 44.4 & 3.7 & 8.6 \\
\hline Average & 19 & 0 & 19.8 & 44.17 & 66.5 & 8.9 & 6.2 \\
\hline
\end{tabular}


The mass media constitutes a main learning resource through which teachers gain knowledge about STS issues. Its contribution to informing the sampled teachers about STS issues was found to be $66.5 \%$. The reason for this is that Egyptian television presents several programmes about various STS issues. A small percentage of the sampled teachers $(8.9 \%)$ reported that discussion with colleagues contributed to knowledge of the target issues. The internet was used as a learning resource among $6.2 \%$ of the participant teachers. Egyptian science teachers do not in general resort to the internet, even though it contains many recent articles and publications about STS issues. This may be due to several of the reasons mentioned by teachers in the questionnaire: a) teachers cannot use the computer; b) they cannot use the internet; c) their knowledge of English is not good; and d) they do not have the financial capacity to use the internet.

\section{Interview results}

This aspect of the research was concerned with establishing the conditions that strengthen or weaken Egyptian science teachers' desire to introduce STS issues as curriculum innovation. By doing so, valuable insights can be gained from teachers into what should be changed and what should be preserved in order to encourage teachers to contemplate STS issues. The data analyses indicated that a number of factors influenced teachers' decisions on whether to integrate STS issues or not.

\section{Factors influencing teachers' decision to integrate STS}

The findings of the data analysis indicated that teachers have three main concerns when deciding about integrating STS issues in the curriculum. These concerns are related to students, teachers, and the nature of STS issues. 
Teachers shared a common belief that science is useless unless it meets the society's needs.

So, the development of science has to conform to social traditions. In this way, science could benefit rather than harm society. Teacher $\mathrm{B}$, for instance, gave an example of his ideas on the "Nuclear issue" and what should be taught to students:

\begin{abstract}
In our Islamic societies, we should encourage research in the peaceful uses of nuclear energy. We may encourage nuclear research in the military field for defence and not attack, since other countries possess this science and can threaten the peace of our country. So the Egyptian science curriculum should include these aspects of the STS issues. Therefore the students become aware of the STS issue and its relationship with their social context (T/B)
\end{abstract}

The teachers considered that developing STS activities helped students to practise science in a meaningful context. Teacher I noted that this could be done by encouraging them to search for the causes of scientific and social problems, and to be part of the discussions in the classroom.

\footnotetext{
When teaching science, the teacher should make it clear to the student why science is taught, why it is important, and how it is related to his environment. If the student does science and feels its value, s/he'll like it. (T/I)
}

Respondents viewed their roles as motivators of the students, encouraging them to learn science through social and technological concepts. They considered that the teacher should stimulate students' thinking about the relationship between science, technology and society.

This can be done by telling a story or asking a question at the beginning of the class. After that various questions are asked and students' answers are attended to so that they feel they are responsible and important. (T/E)

A common belief shared by teachers was that it was very important to engage students in STS topics that could be related to their own lives and experiences. The participants also mentioned that the interests of the students were different now because the world had become more technology-oriented and there were many sources of knowledge available. Teachers could see that today's students were exposed to various sources of knowledge related to STS issues and that this affected teachers' performance. Teacher D, for example, said, 
When I prepare my lessons for the students I bear in mind that there are different sources. Today's student deals with various technologies like the computer, the Internet, the TV, the satellite TV, etc. For this reason, they explain phenomena differently. This pushes me to read and search for information to improve myself academically and professionally. That is, I do my best to cope with the development of the modern age. (T/D)

Teachers stressed the importance of school science for developing students' understanding of socio-scientific issues. Some participants argued that it was important for school science to encourage students to have a 'critical view' of the reporting of science in the media. A teacher was concerned that students should utilise an understanding of STS issues to help them to make decisions about their daily activities, e.g., when they went shopping.

There are so many scientific products that citizens have to make choices about for themselves. I find that commercially, people try and con people with science. You see it in the adverts; you know, use this shampoo and leave the others and all this rubbish about treatment for your skin. (T/L)

A number of teachers expressed the opinion that health-related STS issues had an important role to fulfil in informing their children on matters of health. Particular issues dealt with the physical dangers of drug and alcohol abuse, and such issues could make their students aware of the dangers of these drugs. That could save the government a lot of money and effort in the long run. Teacher A emphasised the importance of health issues:

The market now is full of chemical products that citizens can use for different purposes (e.g. beauty, cleaning, painting). These citizens have to make decisions about which product they are going to use. So, including STS health issues is very important to help students make those decisions and also make them aware of the advantages and disadvantages of these products. (T/A)

Egyptian science teachers see scientific and technological developments as a challenge of which they cannot keep abreast in their current conditions. Most of the participants blamed the teacher education programmes for not having prepared them adequately to cope with these developments, and this was confirmed by a number of the teachers who took part in the interviews. Teacher C offered some reasons for her lack of knowledge about STS issues:

My information resources are the same as those of the students, i.e., television and the newspapers. I don't have any access to writings about these recent developments and I don't know the English language. Our preparation in the university was entirely in Arabic. Besides, my major is physics and chemistry. I can read well within my major but discussion of the STS issues needs more than being informed about one science discipline. (T/C) 


\section{Factors influencing teachers' decision not to integrate STS}

The teachers provided reasons for not being able to implement the STS approach or an STS curriculum initiative because of certain contextual factors. They identified two concerns about including some STS issues in the curriculum. These concerns were related to conditions of implementing STS issues in the curriculum and teachers.

Exams not only had a negative affect on teachers' motivation and the way they taught, but teachers also saw them as a test of their success in teaching science, so they had to do their best according to the standards and aims of the examinations. One teacher commented that:

Students won't pay proper attention to understanding the relationship between science, technology and society, because their primary concern is focused on exams. One can say that science teaching in the preparatory stage is controlled by the exam culture. (T/D)

The outcome of examinations is the main interest of students, parents, and school administrations. Therefore, from the very beginning of the school year teachers are concerned only with exams, which then makes students anxious and obliges them to focus on remembering knowledge, rather than on the implementation of that knowledge in their lives. One teacher commented:

\footnotetext{
The current exam system is the horse and the remaining components of the educational system are the carriage. In other words, the various elements of the educational process including the teacher, the student, the curriculum and administration are not driven by the exams, but by the exams. (T/C)
}

All the participants felt they had a limited amount of time in which to help students achieve the STS goals. They taught in schools with typical class schedules and with class periods varying from 40 to 45 minutes in length, and had to use this limited classroom time efficiently. Teacher L also felt pressurized due to the lack of time. She said: 
As a teacher there is no time for me to do what I would like to do. Sometimes I like to use role play to teach STS issues like pollution or using chemical materials and the effect of these problems on our society and what the students would do if they were decision makers. But because I have fixed content and limited time I try to manage these problems by using discussion or short inquiry. (T/J)

Preparation time was the second area in which participants discussed time constraints. Science teachers had to plan their lessons while taking into account the limited amount of class time. Time was allocated to different topics according to the nature and the weight of the topics. As a result, teachers planned for lessons with different times in mind for their daily and weekly teaching. Their visualizations of the time needed for the STS lessons compared with traditional lessons affected their planning and teaching of STS. The constraint of limited preparation time also tended to influence the respondents' practices for their STS classes and teaching methods. One commented:

\footnotetext{
Much more time is needed for managing and organizing an STS class. Strategies like problem solving, brainstorming or cooperative learning entail group work, and that in turn, means reorganizing the students. So, I recommend that STS lessons are grouped in special units and allocated enough time. (T/B)
}

High classroom density made it difficult for the teacher to guide and help individual students in the manner required by inquiring, problem-solving and cooperative learning techniques. Teachers therefore limited themselves to group teaching techniques to control the students by imposing their own views. This would occur even in their presentation of the STS issues, where they did most of the work through verbal explanation and students listened passively without any kind of participation. In other words, such dense classrooms made the adoption of STS education rather difficult. One respondent said:

The STS method is difficult to use because of the large number of students in the classrooms and the shortness of the class time. (T/D)

Teachers mentioned that there were not enough materials to implement STS in the Egyptian school. They wondered how they could interact with 70 students in a classroom where the students could not find enough seats. The condition of science laboratories was also disappointing. During the field study, it was apparent that each school had a room called 
"Knowledge Resources". This room contained one computer, one overhead projector, one cassette player, one video and one television set. Every teacher, regardless of subject area, had to use the room once a week, not for teaching his/her subject but just to record that $\mathrm{s} / \mathrm{he}$ had actually used it. There were no materials related to science or to STS issues in the room that the teachers could use. Nor were they permitted to borrow any equipment (such as a computer or overhead projector) to use in their classes. In addition, the room was very small and accommodated no more than 25 students. In most of the schools I visited there was no technician to help the teachers or train them to use the equipment or produce materials.

Neither the administration nor the science supervisor encouraged the teachers to tackle the topics in any way that was not in compliance with what was specified in the textbook or the teacher's guide. This was why teachers were unable, in many cases, to refer to technological and social aspects in case this was taken to be a drift away from the specified curriculum. This would make them liable to punishment. One teacher commented:

The school administration allows me to shift away from the content and relate it to social and technological issues to a limited degree that depends on the extent to which I am moving away from the content. At the end of the day, the teacher has to focus on the content and may move away from it only to serve it and to achieve the main (cognitive) aims for the purpose of exams. (T/F)

Teacher specialisation was another factor that guided teachers' decisions about integrating STS issues in the curriculum. Teachers declared that some STS issues were close to their specialisation and some were not. In this respect, one commented that:

I cannot teach all the issues of STS. I only can teach those issues that are mostly biological, since biology is my major. For instance, I cannot teach an issue like "Health and man" as my study in the university was restricted to biology and did not extend to other disciplines like chemistry and physics. (T/E)

Teachers' experience of or background in STS issues was one of the important factors affecting teachers' decisions about integrating some STS issues into the science curricula. Teachers cannot plan to teach what they do not know. For example, Teacher B said: 
I am very confident about teaching some of the STS issues that I am familiar with, such as issues related to air and water. I have acquired enough knowledge about these issues from the media and from reading to help me in my teaching. However, I have never heard of issues like 'star wars' technology and use of space. So, I don't recommend that these issues are included in the curriculum until I have acquired sufficient knowledge about them. (T/B)

\section{Discussion: Sociocultural perspective of the findings of the study}

The results of the present study coincide with the findings of Bybee \& Mau (1986) and Zaitton (1991) that air pollution and air quality represent the most global of problems. Supporting evidence also came from Zaitton (1991) who noted that, from the teachers' viewpoint, 'Human Health' is considered the most important issue in Egypt. However, Bybee \& Mau (1986) affirmed that air and water issues are considered the top-ranked issues because they are clearly related to basic human needs. These results also validate Bybee \& Mau's (1986) argument that 'population growth' was an important causal factor for virtually all other problems, including many not ranked in the top half of the list. According to the Egyptian context, and as the results indicated 'population growth' is considered a causal factor for problems such as land use, energy shortage, world hunger, and food production and plants. The high ranking of population growth indicates that science teachers understand the fundamental nature of this problem (Bybee \& Mau, 1986).

While some teachers supported aspects of an STS curriculum, they felt immense pressure and a lack of material support to successfully implement the reforms of STS curriculum, while also feeling de-professionalized. An array of factors, including a negative political tone and a discord between professional beliefs and new reform mandates, confused many teachers (Lasky, 2005). In this sense, the study emphasises the importance of teachers' professional development about the subject knowledge (STS issues) they expect to teach. In the UK, even though a range of materials have been produced with the aim of helping teachers and students to examine biotechnological socio-political issues, a majority of science teachers considered it 
their role to present the 'facts' of their subject and not to deal with associated social or ethical issues (Levinson \& Turner, 2001). The findings of this study highlight the way the 'subject matter' of the teachers' disciplines might strongly influence their beliefs and teaching practices with regard to STS issues. The conclusion reached in this study is that while STS issues are interdisciplinary some are more closely related to specific disciplines than to others (Aikenhead, 1994; Yager, 1996). For example, certain issues related to military concerns, such as weapons sales and chemical and germ warfare, are interdisciplinary but are much closer to chemistry and physics. On the other hand, STS issues like population growth, birth control, use of fetal tissue, and extinction of plants or animals are also interdisciplinary issues but are much closer to the discipline of biology.

The study indicates that teachers' perceptions of the students' needs and interests acts as Wertsch's (1991) “mediated action," something that controls teachers' views and decisions regarding the development of the science curriculum and the implementation of STS issues. The central claim of Wertsch's research is "that human action typically employs 'meditational means' such as tools and language, and that these meditational means shape the action in essential ways" (p. 12). The action, therefore, is carried out by the individual in a concrete situation with the meditational means involved. In this case, science teachers' experience of our world is shaped by physical and symbolic tools (mediating tools). In the view of Vygotsky (1978), we can see the teacher as an individual-in-society learning and thinking through artefacts.

The combination of negative political and administrative tone, decreased material resources, and a heavy implementation schedule for the new STS curriculum interfered significantly with teachers being adequately prepared or even intending to teach new materials like STS issues. There was more material to be covered, so these teachers relied more on lectures, 
which is not efficient for teaching STS issues (Bryce \& Gray, 2004; Yalvac et al., 2007). With the increased focus on academic achievement by inspectors and the school administration, teachers in this study did not have as much time to build rapport with their students. Teachers and students were both under increased socialization pressure, especially the pressure of exams. The teachers who were interviewed believed that these factors taken together compromised the student learning that STS can achieve but in a friendly constructivist environment (Yager, 2007). The findings of this study concur with France (2007)'s study, which analysed over 1000 questionnaires and interviews from 20 institutions, and revealed that teachers believed they lacked the skills, confidence, and time to initiate and manage classroom discussion about such topics. These teachers felt constrained by the requirements of a formal examination prescription, and believed they could not spend time on these areas.

The educational systems restrict the teachers' professional freedom through a variety of methods (including the examination system and school inspections). These methods limit and control teachers' ways of knowing about STS. Teachers targeted the students' textbooks to achieve their schools' policy on students' achievement. In this respect Bourdieu and Passeron (1990: 58) argue that the teaching tools that the educational system makes available to its agents (manuals, teachers' texts, syllabuses, books, teaching instructions, etc.) must not simply be aids to inculcation but also as instruments of control tending to safeguard the orthodoxy of the work of schooling. This might explain why the teachers, based on their knowledge and interpretation of the policy of the education system, are making decisions that will fit the potentially competing demands of the needs, abilities and interests of their students and the educational contexts.

The findings indicate that teachers perceive the principal sources of constraints as 'external constraints'. This raises the question of why Egyptian teachers feel this way. It is possible 
that they feel that most, if not all, of the decisions related to their career come from the outside in a 'top down' manner. They do not contribute to any decisions regarding curriculum development, teacher training, and teacher preparation and so on, and so do not feel that they have to take responsibility for any changes or innovations (France, 2007; Author, 2008b). This can be explained through the idea of 'teacher agency'. Teacher agency is part of a complex dynamic; it shapes and is shaped by the structural and cultural features of society and school cultures (Datnow, Hubbard, \& Mehen, 2002). In this context, policy mandates are adapted, adopted, or ignored. Each decision teachers make, each action they take, is simultaneously a consequence of past action and present context and a condition shaping the context for further action (Hall \& McGinty, 1997). As the results of the study show, teachers' decisions are mediated by the structural setting such as the knowledge resources available to them, the conditions of teaching science through STS (including lack of time, STS resources, and class size) the norms of their school (e.g. school administration), and the teachers' perceived knowledge.

\section{A final word from the findings}

Research supports the idea that teachers are crucial change agents for educational reform and that teachers' beliefs are precursors to change. From that point, implementing STS in Egyptian science curricula should be based on the contribution of teachers, and their convictions or beliefs about these innovations. The implementation of any innovation that fails to take account of teachers and the teachers' work situation as mediators of that innovation is doomed to fail. Therefore it is essential to take Egyptian teachers' beliefs and practices into account, as well as the factors that shape or influence those beliefs and practices, so that they can be properly dealt with. In this way, this study adds support to the considerable body of literature across different areas of the curriculum which suggests that, unless curriculum developers take account of teachers' beliefs and knowledge in designing 
new curriculum materials, these materials are unlikely to be implemented according to their intended plan (Gayford, 2002; Bryce \& Gray, 2004; France, 2007; Lee \& Witz, 2008).

\section{Acknowledgements}

I would like to thank the three anonymous reviewers for their helpful and valuable comments on the earlier version of this manuscript. I found their comments very insightful and helpful in redirecting of the manuscript and makeing the argument of the paper very clear.

\section{References}

Aikenhead, G. (1994). What is STS science teaching? In J. Solomon \& G. Aikenhead (Eds.), STS education international perspectives on reform (pp.47-59). New York, Teachers College Press.

Aikenhead, G. (2005). Research into STS science education. Educación Química, 16, 384-397, 2005

Ben-Peretz, M. (1980). Teachers' role in curriculum development: An alternative approach.Canadian Journal of Education, 5(2), 52-62.

Bourdieu, P., \& Passeron, J. (1990). Reproduction in education, society and culture. London: SAGE Publications.

Bryce, T., \& Gray, D. (2004). Tough acts to follow: the challenges to science teachers presented by biotechnological progress. International Journal of Science Education, 26(6), 717-733.

Bybee, R. (1984). Global problems and science education policy (pp. 117-127), In R. Bybee (Ed.), Redesigning Science and Technology Education 1985 NSTA Yearbook. Washington, DC: National Science Teachers association.

Bybee, R. (1987). Science education and Science-Technology-Society (S-T-S) theme. Science Education, 71, 667-683.

Bybee, R., \& Bonnstetter, R. (1986). STS: What do science teachers think? (pp. 60-75), In R. Bybee, J. Carlson \& A. McCormack (Eds.), Redesigning Science and Technology Education 1984 NSTA Yearbook. Washington, DC: National Science Teachers association.

Bybee, R., \& Mau, T. (1986). Science and technology related global problems: in international survey of science educators. Journal of Research in Science Teaching, 23(7), (599-618).

Carroll, T. M. (1999). Developing partnerships: teacher beliefs and practices and the STS classroom. Proceedings of the 1999 Annual international conference of the association for the Education Teachers in Science (pp.331-338). Greenville, NC: Association for the Education of Teachers in Science. (ERIC Document Reproduction Service No. ED 431626)

Carter, C. (1991). Science-Technology-Society and Access to Scientific Knowledge. Theory into Practice, Vol. XXX (4), 273-279.

Dadds, M. (1995). Passionate enquiry and school development: A story about teacher action research. London: The Falmmer Press.

Datnow, A., Hubbard, L., \& Mehen, H. (2002). Educational reform implementation: A co-constructed process. London: Routledge.

Denzin, N., \& Lincoln, Y. (2000). Handbook of Qualitative Research, 2nd ed. London: SAGE.

Fensham, P. J. (1988). Approaches to teaching of STS in science education. International journal of science education, 10 (4), 346-356.

Fishbein, M., \& Ajzen, I. (1975). Belief, attitude, intention and behavior: An introduction to theory and research. London: Addison-Wesley.

France, B. (2007). Location, location, location: Positioning biotechnology education for the $21^{\text {st }}$ Century. Studies in Science Education, 43(1), 88-122.

Gayford, C. (2002). Controversial environmental issues: a case study for the professional development of science teachers. International Journal of Science Education, 24(11), 1191-1200.

Heath, P.A. (1992). Organizing for STS teaching and learning: the doing of STS. Theory into Practice, Volume xxxi, 1, winter, 52-58.

Hill, P. W., \& Crevola, C. A. M. (1997). The literacy challenge in Australian primary schools. Seminar Series No. 69. Melbourne, Victoria, Australia: Incorporated Association of Registered Teachers of Victoria (IARTV), 1997, November .

Hofstein, A., Aikenhead, G. S., \& Riquarts, K. (1988). Discussions over STS at the Fourth IOSTE Symposium. International journal of Science Education, 10(4), 357-366.

Howe, A., \& Stubbs, H. (1997). Empowering science teachers: A model for professional development. Journal of Science Teacher Education, 8 (3), 167-182. 
Kagan, D. (1992). Implications of research on teacher belief. Educational Psychologist, 27(1), 65-90.

Lasky, S. (2005). A sociocultural approach to understanding teacher identity, agency and professional vulnerability in a context of secondary school reform, Teaching and Teacher Education, 21, 899-916.

Lee, H., \& Witz, K. (2008). Science Teachers' Inspiration for Teaching Socio-scientific Issues: Disconnection with reform efforts. International Journal of Science Education, i First article, 1-30.

Levinson, R., \& Turner, S. (2001). Valuable lessons: Engaging with the social context of science in schools. Retrieved from Wellcome Trust, Web site: http://www.wellcome.ac.uk/Aboutus/Publications/Reports/Education/WTD003435.htm.

Levitt, K. E. (2001). An analysis of Elementary teachers' beliefs regarding the teaching and learning of science, Science Education, 86, 1-22.

Lichtenstein, G., McLaughlin, M. W., \& Knudsen, J. (1992). 'Teacher empowerment and professional knowledge. In A. Lieberman (Ed.), The changing contexts of teaching (pp. 37-58). Chicago: University of Chicago Press.

Mamlok-Naaman, R., Hofstein, A., \& Penick, J. (2007). Involving science teachers in the development and implementation of Assessment tools for "Science for All" type curricula. Journal of Science Teacher Education, 18, 497-524.

Author (2007). Bulletin of Science, Technology \& Society.

Author (2008a) International Journal of Science Education

Author (2008b). VDM Verlag Dr. Mueller e.K.

Mubarak and education (2006). Cairo: Egypt. The Ministry of Education. Department of Textbooks (in Arabic).

Munby, H. A. (1984). A qualitative approach to the study of a teacher's beliefs. Journal of Research in Science Teaching, 21, 27-38.

Noss, R., \& Hoyles, C. (1996). Windows on mathematical meaning, Dordrecht: Kluwer Academic Publishers.

Pajares, M. F. (1992). Teachers' beliefs and education research: Cleaning up a messy construct. Review of Education Research, 62, 307-332.

Patton, M.Q. (2002). Qualitative research \& evaluation methods (3rd edition). Thousand Oaks, CA: Sage Publications.

Richardson, V. (1997). Constructivist teaching and teacher education: theory and practice, In: V. Richardson (Ed.), Constructivist Teacher Education: building new understandings, (pp. 3-14). London: Falmer.

Rubba, P. A. (1991). Integrating STS into school science and teacher education: Beyond awareness. Theory into Practice, 30, 303-308.

Rubba, P., \& Harkness, W. (1993). Examination of pre-service and in-service science teachers' beliefs about science-technology-society interactions, Science Education 77 (4), 407-31.

Strauss, A., \& Corbin, J. (1998). Basics of qualitative research: Techniques and procedures for developing grounded theory. London: SAGE publications.

Sutherland, A. (1981) Curriculum Projects in Primary Schools: an investigation of project adoption and implementation in 185 Northern Ireland schools. Northern Ireland Council for Educational Research.

Tal, R., Yehudit, J., \& Shoshana, K. (2001). Assessing conceptual change of teachers involved in STES education and curriculum development-the STEMS project approach. International Journal of Science Education. 23(3), 247-262.

Thirumarayana, M. O. (1998). An explanatory study of the relationships among science, technology, and society (STS) issues as conceived by fifth grade students. Journal of Elementary Science Education, 10 (1), 6075.

Tsai, C. (2002). Nested epistemologies: science teachers' beliefs of teaching, learning and science. International Journal of Science Education, 24(8), 771-783.

UNESCO (2006). Decentralization of education in Egypt. Country Report at the UNESCO Seminar on "EFA Implementation: Teacher and Resource Management in the Context of Decentralization" Administrative Staff College of India, Hyderabad, India 6-8 January 2005

Vygotsky, L. S. (1978). Mind in society: The development of higher psychological processes, Cambridge, MA: Harvard University Press.

Wertsch, J. V. (1991). Voices of the mind: A Sociocultural approach to mediated action. Cambridge, MA: Harvard University Press.

Wertsch, J.V., Del Rio, P., \& Alvarez, A. (1995). Sociocultural studies: History, action and mediation. In J.V. Wertsch, P. Del Rio \& A. Alvarez (Eds.), Sociocultural studies of mind (pp. 1-36). Cambridge, MA, Cambridge University Press.

Yager, R. E. (1996). Science/Technology/Society as reform in science education. Albany: State University of New York Press.

Yager, R. E. (2007). The sic "C" pyramid for realizing success with STS instruction. Science Education International, 18(2), 85-92.

Yager, R. E., \& Lutz, M. V. (1995). STS to enhance total curriculum. School Science \& Mathematics, 79(1), 2836.

Yalvac, B., tekkaya, C., Cakiroglu, J., \& Kahyaouglu, E. (2007). Turkish pre-service science teachers' views on Science-Technology-Society issues. International Journal of Science education, 29 (3) 331-348. 
Za'rour, G. I. (1987). Forces hindering the introduction of STS education in schools, In K. Riquarts (Ed.), Science and Technology education and the quality of life (pp. 731-741). Kiel, Germany: Institute for Science education, Kiel University.

Zitton, K. (1991). Science teachers' perspectives concerning Science, technology and society issues. Paper presented at the Third Annual Conference of the Egyptian Council of Curricula and Instruction (ECCE), Alexandria, Egypt, 4-8 August.

\section{Appendix A}

Teachers Questionnaire about STS issues

1- There are many social and global problems confronting humanity. What do you perceive as important science and technology-related social and global problems to be integrated in the preparatory science curriculum? Please Rank the following in order of importance 1, 2, 3, and so on.

- World hunger and food production (food production, agriculture, cropland conservation)

- Population growth (world population, immigration, carrying capacity, foresight capability)

- Air pollution and quality (acid rain, $\mathrm{CO}_{2}$, depletion of ozone, global warming)

- Water resources and quality (waste disposal, estuaries, supply, distribution, ground water contamination, fertilizer, contamination)

- Human health (infectious and non-infectious diseases, noise, diet and nutrition, exercise, mental health)

- Energy shortages (synthetic fuels, solar power, fossil fuels conservation, oil production)

- War Technology (nerve gas, nuclear developments, nuclear arms threat)

- Land use (soil erosion, reclamation, urban development, wildlife habitat loss, deforestation, desertification)

- Hazardous substances (waste dumps, toxic chemicals, lead paints)

- Nuclear reactors (nuclear waste management, breeder reactors, cost of construction, safety, terrorism)

- Extinction of plants and animals (reducing genetic diversity, wildlife protection)

- Mineral resources (non fuel minerals, metallic and non metallic minerals, mining, technology, low grade, deposits, recycling, reuse)

2- What is the extent of your knowledge of each of these issues?

(Please tick $[\sqrt{ }]$ where appropriate).(see table 2 )

3- Which resources facilitate your ability to gain knowledge of these issues?

(Please tick $[\sqrt{ }]$ where appropriate). (see table 3 ) 